\title{
Correction to: Validity of using immunohistochemistry to predict treatment outcome in patients with non-small cell lung cancer not otherwise specified
}

Takahiro Ota $^{1,2,3} \cdot$ Keisuke Kirita $^{1}$ (D) $\cdot$ Reiko Matsuzawa $^{4} \cdot$ Hibiki Udagawa $^{1} \cdot$ Shingo Matsumoto $^{1} \cdot$ Kiyotaka Yoh $^{1}$. Seiji Niho ${ }^{1} \cdot$ Genichiro Ishii $^{2,3} \cdot$ Koichi Goto ${ }^{1}$

Published online: 23 July 2021

(c) Springer-Verlag GmbH Germany, part of Springer Nature 2021

\section{Correction to: Journal of Cancer Research and Clinical Oncology (2019) 145:2495-2506 \\ https://doi.org/10.1007/s00432-019-03012-z}

In the original article published, the number of 6-month PFS and 95\% CI percentages in the table under the Kaplan-Meier curve in Fig. $3 \mathrm{~A}$ and $\mathrm{C}$ are incorrect. The correct figures are given below:

The original article can be found online at https://doi.org/10.1007/ s00432-019-03012-z.

Keisuke Kirita

kkirita@ncc.go.jp

1 Department of Thoracic Oncology, National Cancer Center Hospital East, 6-5-1 Kashiwanoha, Kashiwa, Chiba 277-8577, Japan

2 Division of Pathology, Exploratory Oncology Research and Clinical Trial Center, National Cancer Center, Kashiwa, Chiba, Japan

3 Course of Advanced Clinical Research of Cancer, Juntendo University Graduate School of Medicine, Tokyo, Japan

4 Department of Respiratory Medicine, Nagoya University Graduate School of Medicine, Nagoya, Aichi, Japan 
A

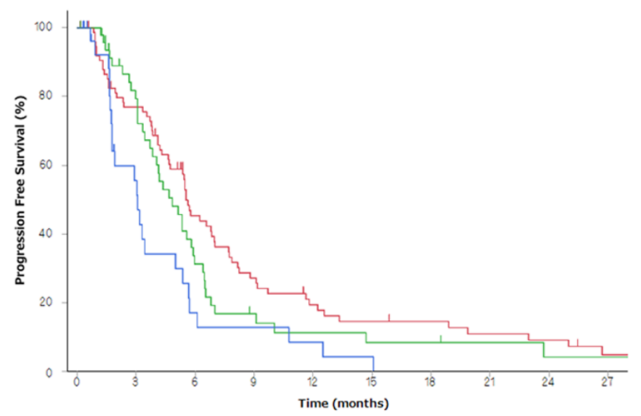

\begin{tabular}{cccc} 
Group & $\begin{array}{c}\text { Median PFS } \\
\text { months (range) }\end{array}$ & $\begin{array}{c}\text { 6-month PFS, } \\
\%(95 \% \text { CI })\end{array}$ \\
\hline- & Favor ADC & $5.5(4.6-6.3)$ & $43(32$ to 55$)$ \\
- & Favor SQC & $4.4(3.4-5.7)$ & $27(15$ to 42$)$ \\
\hline & NOS-null & $3.0(1.7-3.4)$ & $13(4$ to 33$)$ \\
\hline
\end{tabular}

C

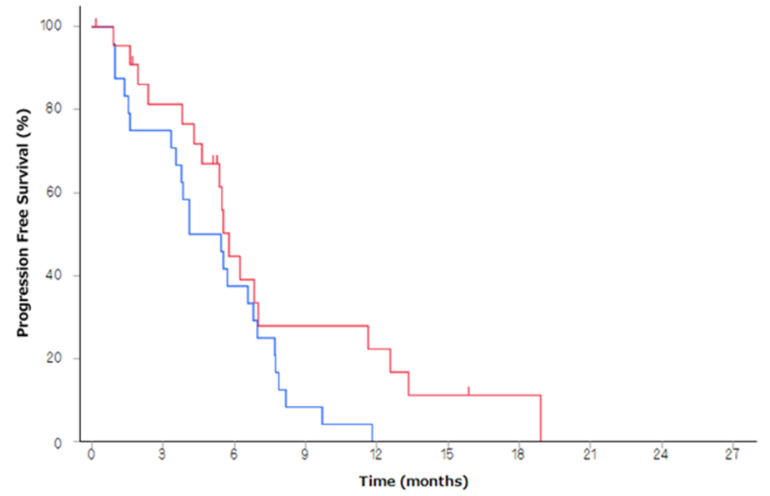

\begin{tabular}{lcc} 
Group & $\begin{array}{c}\text { Median PFS } \\
\text { months (range) }\end{array}$ & $\begin{array}{c}\text { 6-month PFS, } \\
\%(95 \% \text { CI })\end{array}$ \\
\hline PEM-containing & $5.8(4.3-7.0)$ & $39(20$ to 62$)$ \\
other platinum & $4.8(3.3-6.8)$ & $38(21$ to 58$)$ \\
\hline
\end{tabular}

Fig. 3 Kaplan-Meier curves for progression-free survival (PFS) and overall survival (OS). a PFS and b OS in the favor adenocarcinoma (ADC) group, favor squamous cell carcinoma (SQC) group, and not otherwise specified (NOS)-null group. c PFS and
B

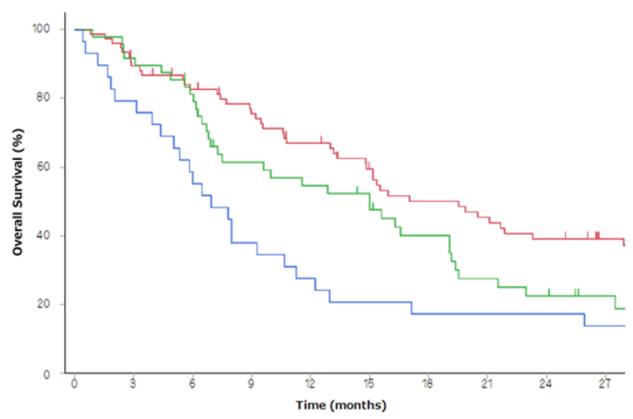

\begin{tabular}{ccccc} 
Group & & $\begin{array}{c}\text { Median OS } \\
\text { months (range) }\end{array}$ & $\begin{array}{c}\text { 1-year OS, } \\
\%(95 \% \mathrm{CI})\end{array}$ & $\begin{array}{c}\text { 2-year OS, } \\
\%(95 \% \mathrm{CI})\end{array}$ \\
\hline- & Favor ADC & $19.5(14.8-27.9)$ & $67(55$ to 77$)$ & $39(28$ to 51$)$ \\
- & Favor SQC & $15.0(7.3-19.1)$ & $51(37$ to 65$)$ & $20(10$ to 35$)$ \\
- & NOS-null & $6.9(4.3-10.7)$ & $20(10$ to 39$)$ & $7(2$ to 24$)$ \\
\hline
\end{tabular}

D

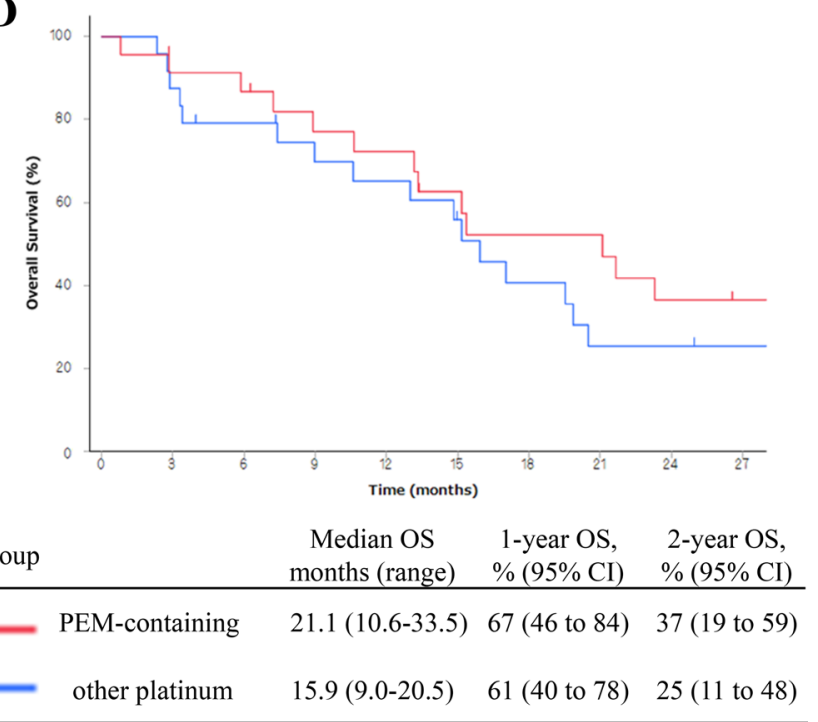

d OS in the favor adenocarcinoma (ADC) group for patients receiving a pemetrexed (PEM)-containing regimen or other platinum regimen. $A D C$ adeno-carcinoma, $S Q C$ squamous cell carcinoma, NOS not otherwise speci-fied

Publisher's Note Springer Nature remains neutral with regard to jurisdictional claims in published maps and institutional affiliations. 